\title{
The Effect of Irrigation Method, Water-soluble Fertilization, Replant Nutrient Charge, and Surface Evaporation on Early Vegetative and Root Growth of Poinsettia
}

\author{
William R. Argo' and John A. Biernbaum ${ }^{2}$ \\ Department of Horticulture, Michigan State University, East Lansing, MI 48824-1325
}

Additional index words. Euphorbia pulcherrima, soluble salts, subirrigation

\begin{abstract}
Rooted cuttings of 'Gutbier V-I 4 Glory poinsettia (Euphorbia pulcherrima Willd. ex Klotzsch) were grown in 15$\mathrm{cm}$ pots using two irrigation methods, two water-soluble fertilization schedules, and two preplant root-media fertilization rates. No difference in shoot growth occurred with either top watering with $33 \%$ leaching or subirrigation. The top $2.5 \mathrm{~cm}$ (top layer) contained nutrient concentrations up to 10 times higher than those measured in the remaining root medium (root zone) of the same pot with both irrigation methods. Constant applications of $28 \mathrm{~mol} \mathrm{~N} / \mathrm{m}^{3}$ water-soluble fertilizer (WSF) limited shoot and root growth as measured at 3 and 8 weeks compared to a weekly increase in the concentration of WSF from 0 to $28 \mathrm{~mol} \mathrm{~N} / \mathrm{m}^{3}$ in $7 \mathrm{~mol} \mathrm{~N} / \mathrm{m}^{3}$ increments over a S-week period. The additional incorporation of $0.27 \mathrm{~kg} \cdot \mathrm{m}^{-3} \mathrm{mineral} \mathrm{N}$ to Metro Mix 510 before planting had no effect on fresh- or dry-weight accumulation. When the root-medium surface was covered by an evaporation barrier, $46 \%$ less water and $41 \%$ less $\mathrm{N}$ fertilizer were applied to plants of similar size, and higher root-zone nutrient levels were maintained over the 8 weeks of the experiment. The evaporation barrier had the greatest effect on increasing root-zone nutrient concentrations and reducing the growth of subirrigated plants.
\end{abstract}

Sheldrake (1987) and Berghage et al. (1987) recommend watersoluble fertilizer (WSF) concentrations of $28 \mathrm{~mol} \mathrm{~N} / \mathrm{m}^{3}$ for the first 3 weeks of production. after which the concentration should be reduced to $21 \mathrm{~mol} \mathrm{~N} / \mathrm{m}^{3}$ until 2 weeks before the plant is to be shipped to market. This recommendation is also commonly found on bags of commercially available WSF designed specifically for poinsettia production. Berghage et al. (1987) suggest that the high initial WSF concentrations are required due to the high nutritional requirements of poinsettias during early vegetative growth.

Another method of quickly increasing the nutrient concentration of a root medium is to incorporate the nutrients before planting. Most commercially available root media contain a preplant nutrient charge (PNC) that includes N. Bunt (1988) reconmends the incorporation of no more than 0.20 to $0.25 \mathrm{~kg} \mathrm{~N} / \mathrm{m}^{3}$ of root media before planting because higher amounts may cause soluble salt damage to plants.

Maintaining acceptable root-medium nutrient concentration after planting depends on the concentration of the applied WSF and the amount of water leached from the pot in top-watered plants. It is commonly recommended to apply WSF with an excess of $10 \%$ to $15 \%$ at every watering to reduce fertilizer salt buildup (Nelson, 1991). Yelanich and Biernbaum (1993) found that leaching fractions above $35 \%$ were required to maintain root-medium nutrient concentrations within recommended soil test levels with WSF concentrations above $14 \mathrm{~mol} \mathrm{~N} / \mathrm{m}^{3}$ applied at every irrigation. Similar root-medium nutrient concentrations could be maintained when $28 \mathrm{~mol} \mathrm{~N} / \mathrm{m}^{3}$ was applied with a $50 \%$ teaching fraction. or 14 $\mathrm{mol} \mathrm{N} / \mathrm{m}^{3}$ with a $15 \%$ teaching fraction.

Fertilizer salts arc not leached from the root medium with flood subirrigation of container-grown plants. Subirrigation can pro-

Received for publication 24 June 1994. Accepted for publication 15 Nov. 1994. We acknowledge the Michigan Agricultural Experiment Station and the American Floral Endowment for the support of this research. The use of trade names in this publication does not imply endorsement of the products named. nor criticism of similar ones not mentioned. The cost of publishing this paper was defrayed in part by the payment of page charges. Under postal regulations. this paper therefore must be hereby marked adiertisement solely to indicate this tiact.

Graduate rescarch assistant.

Associate professor. duce plants equal in quality to top-watered plants with one-half the concentration of WSF (George, 1989). However. fertilizer salts tend to accumulate in the top 2 to $3 \mathrm{~cm}$ of the root medium because of evaporation of water from the root-medium surface (Argo and Biernbaum, 1994: George, 1989: Guttormsen, 1969; Havis, 1982: Molitor, 1990).

Laurie and Ries (1950) commented on the large amount of water lost by evaporation from sphagnum peat because of a wicking effect caused by the peat fibers. Beardsell et al. (1979) found that sphagnum peat lost much more water to evaporation than other organic and inorganic components. Furuta et al. (1977) reduced evapotranspiration by $26 \%$ by placing a plastic disk over the root-medium surface.

Davis (1982) found that the vertical distribution of fertilizer salts in the root medium was different when the surface of the pot was covered with an evaporation barrier (EB) compared to that in pots left uncovered. In 12-cm-tall pots. a higher electrical conductivity (EC) was measured in the top $4 \mathrm{~cm}$ of the root medium than in lower levels when the surface was uncovered. When an EB was placed on the root-medium surface. a higher EC was measured at the 4 - to $8-\mathrm{cm}$ level. The decreased quality of azaleas with the barrier at the high incorporated rate of resin-coated fertilizer (3.0 $\mathrm{kg} \cdot \mathrm{m}^{-3}$ ) was attributed to the reduction in salt stratification.

The objectives of this experiment were to investigate how irrigation method. early fertilization. and evaporation from the root-medium surface interact to affect root-medium nutrient concentrations and vegetative growth of poinsettias at two stages of development.

\section{Materials and Methods}

The four factors in this experiment were 1) irrigation method. 2) WSF regime, 3) preplant nutrient charge. and 4) the presence of an EB. The experimental design was a split-plot factorial, with irrigation as the main plot and the other three factors as subplots. Each factor had two levels with six samples at two sampling dates for a total of 192 pots. Data were analyzed using SAS's analysis of variance (ANOVA) procedures (SAS Institute. 1982). Statistical analysis of the root-to-shoot $(\mathrm{R}: \mathrm{S})$ ratio was determined only for 
the plants with both root and shoot data by ANOVA of the arcsin transformation of the ratio.

Irrigation method. Top watering with $33 \%$ leaching was conpared to subirrigation. Plants were initially irrigated with 0.3 liters using the desired irrigation and fertilization method. Thereafter, each treatment was irrigated independently when the average mass of three pots reached 750 to $800 \mathrm{~g}$. At this mass, $\approx 25 \%$ to $35 \%$ of the total available water held at container capacity remained in the media. The same three sample pots from each treatment were weighed daily to determine if the target mass was reached.

For the top-watered treatments. 0.75 liters of solution was applied to the root-medium surface, the pots were allowed to drain for $30 \mathrm{~min}$. and the three sample pots were reweighed. The difference in mass before and after the irrigation was the amount of water absorbed by the media $(\approx 0.5$ liter of solution was absorbed after a typical irrigation) and was recorded for each irrigation. For the subirrigated treatments. 0.325 liter of water or fertilizer solution was placed into a $17-\mathrm{cm}$ plastic saucer and absorbed through the bottom of the pot. The amount of solution applied to subirrigated pots reflected the amount of water that could he absorbed in $30 \mathrm{~min}$. Subirrigated pots were not weighed after an irrigation since all applied solution was absorbed.

Water-soluble fertilizer regime. The constant application of 28 mol N/m ${ }^{3}$ (CLF) was compared to the scheduled weekly increase of $7 \mathrm{~mol} \mathrm{~N} / \mathrm{m}^{3}$ in applied WSF from 0 to $28 \mathrm{~mol} \mathrm{~N} / \mathrm{m}^{3}$ over a 5 -week period (SLF). A given concentration was applied for only 1 week. Treatments not irrigated for that week did not receive what particu lar concentration. After week 5, all treatments received the $28 \mathrm{~mol}$ $\mathrm{N} / \mathrm{m}^{3}$ solution. A commercial WSF $[15 \mathrm{~N}-2.2 \mathrm{P}-20.1 \mathrm{~K}$ Poinsettia Special (Grace/Sierra, Fogelsville, Pa.)] that contained $70 \% \mathrm{NO}_{3}$ -N and supplied 28-1.9-14.1 mol N-P-K/m $/ \mathrm{m}^{3}$ at the $28 \mathrm{~mol} \mathrm{~N} / \mathrm{m}^{3}$ rate. was used. The volume of each fertilizer application was recorded at each irrigation.

Preplant nutrient change. The base preplant nutrient charge (BPNC) of Metro Mix 510 produced an EC of $2.06 \mathrm{dS} \cdot \mathrm{m}^{-1}$ with 7.9 mol $\mathrm{NO}_{3}-\mathrm{N} / \mathrm{m}^{3}$ in a saturated medium extract (SME) (Warncke 1986). The higher preplant nutrient charge (HPNC) consisted of the same root medium. hut was amended with $0.6 \mathrm{~kg} \cdot \mathrm{m}^{-3} \mathrm{KNO}_{3}$, $0.6 \mathrm{~kg} / \mathrm{m}^{3} \mathrm{Ca}\left(\mathrm{NO}_{3}\right)_{2}$. and $0.3 \mathrm{~kg} \cdot \mathrm{m}^{-3} \mathrm{~N} \mathrm{H}_{4} \mathrm{~N} \mathrm{O}_{3}$. The additional fertilizer salts increased the EC of the root medium to $3.51 \mathrm{dS} \cdot \mathrm{m}^{-1}$ with $34.3 \mathrm{~mol} \mathrm{NO}_{3}-\mathrm{N} / \mathrm{m}^{3}$.

Evaporation barrier. The EB was made from a $15-\mathrm{cm}$ polysty rene plate that was placed on the root-medium surface. A hole was melted in the middle of the plate for the plant stem. and a cut was made from the perimeter to the center so the cover could he inserted after planting. Three smaller holes were also placed in the plate to allow surfaceapplied water to drain into the root medium below. The barrier was placed on half the pots at planting before the first irrigation.

The experiment was conducted in a well-ventilated glasshouse with constant air circulation and cement floors. The irrigation water used had an EC of $0.6 \mathrm{dS} \cdot \mathrm{m}^{-1}$, an alkalinity to $\mathrm{pH} 4 \mathrm{of} 310 \mathrm{mg}$ $\mathrm{CaCO}_{3} /$ liter, and a nutrient concentration of $2.0 \mathrm{~mol} \mathrm{Ca}{ }^{2+} / \mathrm{m}^{3} .1 .6$ mol $\mathrm{Mg}^{2+} / \mathrm{m}^{3}$, and $1.0 \mathrm{~mol} \mathrm{Na} / \mathrm{m}^{3}$. Rooted 'Gutbier V-14 Glory' poinsettia cuttings were planted into $15 \times 15-\mathrm{cm}(1.7-$ liter $)$ green plastic pots containing root medium on 30 Mar. 1990 and were grown with a day/night setpoint of 24/21C. Plants were kept vegetative by either a 4-h night-break interruption (2200 to 0200 HR) from incandescent lights or normal daylength.

At planting, the nodal location of the most recent fully expanded leaf was marked on the stem with a permanent marker $(\approx 1.5$ to 2.0 $\mathrm{cm}$ above the soil line). All shoot growth measurements were made relative to this mark. After 3 weeks, plant height, shoot fresh and dry weight, and leaf area were measured from six plants from each treatment. Leaf area was determined using an area meter (Delta-T: Decagon Devices, Pullman. Wash.). Three of the six pots were used to determine root fresh and dry weight and $\mathrm{R}: \mathrm{S}$ ratio. The roots were separated from the medium by gently washing in tap water. Minimal root loss was apparent during separation. The remaining three pots were used for root-media sampling. The top $2.5 \mathrm{~cm}$ of root medium (top layer) was removed and tested separately from the remaining root media in the pot (root zone) using the SME technique with reverse-osmosis-purified water as the extractant (Warncke, 1986). The EC of the extracted solution was determined using a platinum electrode at a standard $25 \mathrm{C}$, and $\mathrm{NO}_{3}-\mathrm{N}$ was determined with a nitrate-specific electrode (model 93-07: Orion Research. Cambridge, Mass.).

The remaining plants were pinched using a soft pinch with leafremoval technique (Berghage et al.. 1987). leaving 9 to 11 nodes on a plant. Plants were grown for another 5 weeks. at which time similar data were collected.

Plant water use was calculated by totaling the amount of water remaining in the pot after each irrigation for top watering and totaling the amount of water applied for subirrigation. Applied $\mathrm{N}$ from WSF was calculated from the total water applied for both irrigation treatments multiplied by the $\mathrm{N}$ concentration of the applied fertilizer solution.

\section{Results and Discussion}

Root medium nutrient levels. At 21 days after planting, EC and $\mathrm{NO}_{3}-\mathrm{N}$ concentrations of the uncovered pots were greater in the top layer than in the root zone with both irrigation methods (Table 1). High concentrations of voluble salts are commonly reported in the top layer with subirrigation (Argo and Biernbaum. 1994: George. 1989: Guttormsen, 1969; Havis, 1982: Molitor. 1990; Yelanich, 1991). Reports of this same type of salt stratification with top watering have been varied. For example, Yelanich (1991) measured $2.5 \%$ greater amounts of $\mathrm{NO}_{3}-\mathrm{N}$ in the top layer compared to those in the root zone of top-watered pots with up to $70 \%$ leaching. In contrast. $\mathrm{Ku}$ and Hershey (1991) measured lower amounts of soluble salts in the top layer compared to those in the root zone of top-watered pots with up to $40 \%$ leaching.

When the root-medium surface was covered by an EB, the large difference in soluble salt concentrations between the root zone and top layer did not occur (Table 1). With top watering. nutrient levels were higher in the root zone at the second harvest. results similar to those reported by $\mathrm{Ku}$ and Hershey (1991). Soluble-salt stratification occurred within the covered subirrigated pots. hut was less than that measured in the uncovered subirrigated pots at both sampling dates (top layer EC at harvest $1=6.3 \mathrm{vs} .15 .6 \mathrm{dS} \cdot \mathrm{m}^{-1}$ and harvest $2=8.6$ vs. $30.8 \mathrm{dS} \cdot \mathrm{m}^{-1}$. respectively), results similar to those reported by Argo and Biernbaum (1994).

After 54 days, irrigation method. WSF regime. and surface evaporation influenced the accumulation of soluble salts in the top layer. The EC of the top layer was higher in subirrigated pots than in top-watered pots and for plants receiving CLF compared to SLF. However, the difference was greater in the uncovered pots (subirrigated $=30.8 \mathrm{dS} \cdot \mathrm{m}^{-1}$ vs. top water $=10.7 \mathrm{dS} \cdot \mathrm{m}^{-1} ; \mathrm{CLF}=23.5$ $\mathrm{dS} \cdot \mathrm{m}^{-1}$ vs. $\mathrm{SLF}=18.0 \mathrm{dS} \cdot \mathrm{m}^{-1}$ ) compared to the covered pots (subirrigated $=8.6 \mathrm{dS} \cdot \mathrm{m}^{-1}$ vs. top watered $=4.2 \mathrm{dS} \cdot \mathrm{m}^{-1} ; \mathrm{CLF}=6.7$ $\mathrm{dS} \cdot \mathrm{m}^{-1}$ vs. SLF $\left.=6.1 \mathrm{dS} \cdot \mathrm{m}^{-1}\right)$. Similar trends were found with $\mathrm{NO}_{3}$ -N concentrations.

Root-lone $\mathrm{EC}$ and $\mathrm{NO}_{3}-\mathrm{N}$ concentrations in uncovered pots after 21 days were affected by WSF and PNC but not directly by irrigation method (Table 1). Plants receiving the CLF had a higher 


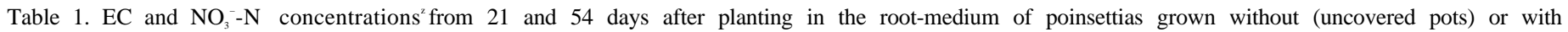
the root-medium surface covered with an evaporation barrier (covered pots). Top layer, top $2.5 \mathrm{~cm}$ of the root medium; root zone, remaining root medium in the pot; CLF = constant liquid fertilizer; SLF = schedule-increasing liquid fertilizer; BPNC = base preplant nutrient charge; HPNC = high preplant nutrient charge. Data represent the mean of three samples.

\begin{tabular}{|c|c|c|c|c|c|c|c|c|c|}
\hline \multirow[b]{3}{*}{ Pots } & & \multicolumn{4}{|c|}{$\mathrm{EC}\left(\mathrm{dS} \cdot \mathrm{m}^{-1}\right)$} & \multicolumn{4}{|c|}{$\mathrm{NO}_{3}^{-}-\mathrm{N}\left(\mathrm{mol} \cdot \mathrm{m}^{-3}\right)$} \\
\hline & & \multicolumn{2}{|c|}{21 Days } & \multicolumn{2}{|c|}{54 Days } & \multicolumn{2}{|c|}{21 Days } & \multicolumn{2}{|c|}{54 Days } \\
\hline & & $\begin{array}{c}\text { Top } \\
\text { layer }\end{array}$ & $\begin{array}{l}\text { Root } \\
\text { zone }\end{array}$ & $\begin{array}{c}\text { Top } \\
\text { layer }\end{array}$ & $\begin{array}{l}\text { Root } \\
\text { zone }\end{array}$ & $\begin{array}{l}\text { Top } \\
\text { layer }\end{array}$ & $\begin{array}{l}\text { Root } \\
\text { zone }\end{array}$ & $\begin{array}{c}\text { Top } \\
\text { layer }\end{array}$ & $\begin{array}{l}\text { Root } \\
\text { zone }\end{array}$ \\
\hline \multicolumn{10}{|l|}{ Uncovered } \\
\hline \multicolumn{10}{|l|}{ Top watered } \\
\hline CLF & BPNC & 11.71 & 2.75 & 12.24 & 4.86 & 99.1 & 23.7 & 107.0 & 46.3 \\
\hline $\mathrm{CLF}$ & HPNC & 14.40 & 3.63 & 12.53 & 4.16 & 128.9 & 32.4 & 113.4 & 39.0 \\
\hline SLF & BPNC & 5.99 & 1.61 & 8.81 & 4.75 & 41.2 & 12.1 & 74.9 & 45.9 \\
\hline SLF & HPNC & 6.82 & 1.91 & 9.09 & 4.08 & 52.7 & 16.4 & 80.9 & 47.7 \\
\hline \multicolumn{10}{|l|}{ Subirrigated } \\
\hline CLF & BPNC & 15.50 & 2.82 & 32.83 & 4.19 & 129.6 & 23.8 & 338.2 & 38.6 \\
\hline CLF & HPNC & 20.11 & 3.30 & 36.32 & 3.87 & 185.6 & 29.3 & 374.9 & 34.3 \\
\hline SLF & BPNC & 8.97 & 1.17 & 24.22 & 4.27 & 47.9 & 9.2 & 241.3 & 41.0 \\
\hline SLF & HPNC & 17.70 & 1.44 & 29.66 & 4.67 & 155.5 & 13.2 & 297.5 & 44.3 \\
\hline \multicolumn{10}{|l|}{ Covered } \\
\hline \multicolumn{10}{|l|}{ Top watered } \\
\hline CLF & BPNC & 3.61 & 3.19 & 4.47 & 4.95 & 26.1 & 20.7 & 39.7 & 44.9 \\
\hline CLF & HPNC & 4.48 & 4.54 & 4.23 & 4.94 & 36.1 & 38.0 & 37.3 & 43.1 \\
\hline SLF & BPNC & 1.79 & 1.76 & 4.21 & 5.00 & 10.3 & 10.3 & 37.1 & 45.5 \\
\hline SLF & HPNC & 2.70 & 2.78 & 3.90 & 4.69 & 21.1 & 21.2 & 36.4 & 42.1 \\
\hline \multicolumn{10}{|l|}{ Subirrigated } \\
\hline CLF & BPNC & 4.33 & 3.09 & 9.31 & 5.88 & 19.3 & 21.5 & 71.2 & 54.0 \\
\hline CLF & HPNC & 8.74 & 5.14 & 8.78 & 5.21 & 73.7 & 44.3 & 78.1 & 49.1 \\
\hline SLF & BPNC & 4.10 & 1.78 & 8.13 & 6.93 & 14.2 & 8.6 & 57.3 & 65.2 \\
\hline SLF & HPNC & 8.18 & 3.85 & 8.27 & 5.00 & 67.0 & 32.2 & 76.4 & 46.1 \\
\hline \multicolumn{10}{|l|}{ Significance } \\
\hline Irrigation method (IM) & & $*$ & NS & $* * *$ & NS & $*$ & NS & $* * *$ & NS \\
\hline Fertilization regime (FR) & & $* * *$ & $* * *$ & $* * *$ & $*$ & $* * *$ & $* * *$ & $* * *$ & $* * *$ \\
\hline Preplant nutrient charge (PNC) & & $* * *$ & $* * *$ & NS & $* * *$ & $* * *$ & $* * *$ & * & $* * *$ \\
\hline $\mathrm{FR} \times \mathrm{PNC}$ & & NS & * & NS & NS & NS & $*$ & NS & NS \\
\hline $\mathrm{IM} \times \mathrm{FR}$ & & NS & NS & NS & NS & NS & NS & $*$ & NS \\
\hline $\mathrm{IM} \times \mathrm{PNC}$ & & $* * *$ & $* *$ & NS & NS & $* * *$ & $* *$ & * & * \\
\hline $\mathrm{IM} \times \mathrm{FR} \times \mathrm{PNC}$ & & NS & NS & NS & NS & NS & $*$ & NS & $*$ \\
\hline Evaporation barrier (EB) & & $* * *$ & $* * *$ & $* * *$ & $* *$ & $* * *$ & $* * *$ & $* * *$ & $* * *$ \\
\hline $\mathrm{IM} \times \mathrm{EB}$ & & $* *$ & $* * *$ & $* * *$ & $* *$ & $* *$ & $* * *$ & $* * *$ & $* * *$ \\
\hline $\mathrm{FR} \times \mathrm{EB}$ & & $* * *$ & NS & $* * *$ & NS & $* * *$ & NS & $* * *$ & NS \\
\hline $\mathrm{PNC} \times \mathrm{EB}$ & & NS & $* * *$ & * & $* *$ & NS & $* * *$ & NS & $* *$ \\
\hline $\mathrm{FR} \times \mathrm{PNC} \times \mathrm{EB}$ & & NS & NS & NS & $* *$ & NS & NS & NS & $* * *$ \\
\hline $\mathrm{IM} \times \mathrm{FR} \times \mathrm{EB}$ & & NS & $*$ & NS & NS & NS & NS & NS & NS \\
\hline $\mathrm{IM} \times \mathrm{PNC} \times \mathrm{EB}$ & & NS & $* * *$ & NS & $* *$ & NS & $* * *$ & NS & $* *$ \\
\hline $\mathrm{IM} \times \mathrm{FR} \times \mathrm{PNC} \times \mathrm{EB}$ & & NS & NS & NS & NS & NS & NS & NS & NS \\
\hline
\end{tabular}

${ }^{2}$ Acceptable EC and $\mathrm{NO}_{3}^{-}-\mathrm{N}$ levels for an SME extract are 0.75 to $2.00 \mathrm{dS} \cdot \mathrm{m}^{-1}$ and 2.8 to $7 \mathrm{~mol} \cdot \mathrm{m}^{-3}$, respectively. Optimal EC and $\mathrm{NO}_{3}^{-}-\mathrm{N}$ levels for an SME extract are 2.00 to $3.50 \mathrm{dS} \cdot \mathrm{m}^{-1}$ and 7 to $14 \mathrm{~mol} \cdot \mathrm{m}^{-3}$, respectively (Warncke and Krauskopf, 1983).

${ }^{\text {Ns }}, *, * * * * *$ Nonsignificant or significant at $P=0.05,0.01,0.001$, respectively.

average $\mathrm{EC}$ and $\mathrm{NO}_{3}^{-}-\mathrm{N}$ concentration than plants receiving SLF (3.1 vs. $1.5 \mathrm{dS} \cdot \mathrm{m}^{-1}$ and 27 vs. $13 \mathrm{~mol} \mathrm{~N} / \mathrm{m}^{3}$, respectively). Plants grown in root medium containing HPNC had a higher average EC and $\mathrm{NO}_{3}^{-}-\mathrm{N}$ concentration than those in root medium containing the BPNC (2.6 vs. $2.1 \mathrm{dS} \cdot \mathrm{m}^{-1}$ and 23 vs. $17 \mathrm{~mol} \mathrm{~N} / \mathrm{m}^{3}$, respectively). In general, nutrient concentrations in the root zone were at optimal levels for the SME with CLF and were within acceptable levels with SLF (Warncke and Krauskopf, 1983).

With the $\mathrm{EB}$, average root-zone $\mathrm{EC}$ and $\mathrm{NO}_{3}^{-}-\mathrm{N}$ concentrations were higher than for uncovered pots, but the difference was greater with subirrigation than with top watering. Covered pots containing the HPNC media had a higher root-zone EC and $\mathrm{NO}_{3}^{-}-\mathrm{N}$ concentration than those of the uncovered pots with HPNC media, but the difference was greater with subirrigation than with top watering.

WSF regime, PNC, and surface evaporation were the main factors affecting the maintenance of root-zone nutrient concentration at the second harvest. Irrigation method also influenced rootzone nutrient concentration, but the effect depended on the presence of the EB. For example, root-zone EC was similar for top watered and subirrigated pots (4.5 vs. $4.3 \mathrm{dS} \cdot \mathrm{m}^{-1}$, respectively). Root-zone EC was higher when the surface was covered with the EB, but the difference compared to the uncovered treatments was greater with 
subirrigation than with top watering ( 5.8 vs. $4.9 \mathrm{dS} \cdot \mathrm{m}^{-1}$, respectively). Similar trends were measured with $\mathrm{NO}_{3}^{-}-\mathrm{N}$ concentrations.

By day 54, root-zone nutrient concentrations in all the treatments were $>3 . .5 \mathrm{dS} \cdot \mathrm{m}^{-1}$, higher than the optimal level recommended for an SME (Warncke and Krauskopf, 1983). Yelanich and Biernbaum (1993) also determined that with top watering, higher fertilizer concentrations required higher leaching fractions to maintain root-zone nutrient concentrations at or below the recommended $3.5 \mathrm{dS} \cdot \mathrm{m}^{-1}$. In this experiment, leaching fractions $>33 \%$ would have been necessary to maintain root-medium nutrient levels in the recommended range with a WSF concentration of $28 \mathrm{~mol} \mathrm{~N} / \mathrm{m}^{3}$.

Plant growth. After 21 days, irrigation method had no direct effect on plant growth (Table 2). SLF plants had greater shoot height, shoot fresh and dry weight, leaf area, and root dry weight compared to those of CLF plants, but the reduction in the growth characteristics with CLF was greater with subirrigation than with top watering. Increasing the PNC did not affect the growth of plants in the uncovered pots. However, when the root-medium surface was covered with an $\mathrm{EB}$, there was a decrease in the five characteristics of plants grown in media containing the HPNC. For shoot height, leaf area, root dry weight, and $\mathrm{R}: \mathrm{S}$ ratio, the decrease with HPNC was greater with subirrigation than with top watering.

High concentrations of WSF $\left(28 \mathrm{~mol} \mathrm{~N} / \mathrm{m}^{3}\right)$ early in development limited plant growth with both irrigation methods, contrary to the current recommendations for early poinsettia fertilization (Berghage et al., 1987; Sheldrake, 1987). Plants with the greatest shoot fresh and dry weight were grown with root-zone nutrient levels considered acceptable for an SME (Warncke and Krauskopf, 1983), but low for poinsettias (Berghage et al., 1987; Sheldrake,

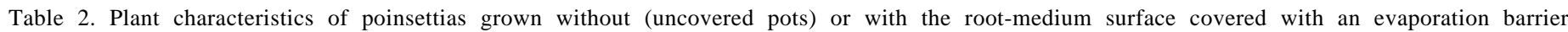
(covered pots) 21 and 54 days after planting. CLF = constant liquid fertilizer; SLF = schedule-increasing liquid fertilizer: BPNC = base preplant nutrient charge; HPNC $=$ high preplant nutrient charge. Data represent the average of six samples.

\begin{tabular}{|c|c|c|c|c|c|c|c|c|c|c|c|c|c|}
\hline \multirow[b]{2}{*}{ Pots } & & \multicolumn{6}{|c|}{21 Days after planting } & \multicolumn{6}{|c|}{54 Days after planting } \\
\hline & & $\begin{array}{c}\text { Shoot } \\
\text { ht } \\
(\mathrm{cm})\end{array}$ & $\begin{array}{c}\text { Shoot } \\
\text { fresh wt } \\
(\mathrm{g})\end{array}$ & $\begin{array}{l}\text { Shoot } \\
\text { dry wt } \\
(\mathrm{g})\end{array}$ & $\begin{array}{l}\text { Leaf } \\
\text { area } \\
\left(\mathrm{cm}^{2}\right)\end{array}$ & $\begin{array}{c}\text { Root } \\
\text { dry wt } \\
(g)\end{array}$ & $\begin{array}{l}\text { Root: } \\
\text { shoot } \\
\text { ratio }\end{array}$ & $\begin{array}{c}\text { Shoot } \\
\mathrm{ht} \\
(\mathrm{cm}) \\
\end{array}$ & $\begin{array}{c}\text { Shoot } \\
\text { fresh wt } \\
(\mathrm{g})\end{array}$ & $\begin{array}{l}\text { Shoot } \\
\text { dry wt } \\
(\mathrm{g})\end{array}$ & $\begin{array}{l}\text { Leaf } \\
\text { area } \\
\left(\mathrm{cm}^{2}\right)\end{array}$ & $\begin{array}{c}\text { Root } \\
\text { wt } \\
(\mathrm{g})\end{array}$ & $\begin{array}{c}\text { Root: } \\
\text { shoot } \\
\text { ratio }\end{array}$ \\
\hline \multicolumn{14}{|c|}{ Uncovered } \\
\hline \multicolumn{14}{|c|}{ Top watered } \\
\hline CLF & BPNC & 9.1 & 7.19 & 1.19 & 272 & 0.26 & 0.202 & 17.0 & 54.00 & 7.98 & 1869 & 0.89 & 0.119 \\
\hline CLF & HPNC & 9.5 & 7.45 & 1.18 & 288 & 0.40 & 0.393 & 14.8 & 44.94 & 6.91 & 1608 & 0.66 & 0.104 \\
\hline SLF & BPNC & 10.2 & 8.56 & 1.29 & 309 & 0.53 & 0.479 & 19.6 & 70.57 & 10.24 & 2483 & 1.60 & 0.166 \\
\hline SLF & HPNC & 9.3 & 8.42 & 1.32 & 304 & 0.62 & 0.505 & 21.2 & 78.13 & 11.65 & 2636 & 1.54 & 0.144 \\
\hline \multicolumn{14}{|c|}{ Subirrigated } \\
\hline CLF & BPNC & 8.3 & 6.97 & 1.10 & 265 & 0.49 & 0.462 & 18.7 & 56.49 & 8.32 & 2055 & 1.63 & 0.190 \\
\hline CLF & HPNC & 9.0 & 6.84 & 1.10 & 276 & 0.31 & 0.266 & 17.1 & 52.10 & 7.79 & 1917 & 1.85 & 0.248 \\
\hline SLF & BPNC & 10.0 & 8.82 & 1.44 & 327 & 0.64 & 0.450 & 20.3 & 73.74 & 10.62 & 2678 & 2.14 & 0.205 \\
\hline SLF & HPNC & 9.3 & 7.22 & 1.25 & 312 & 0.32 & 0.241 & 20.6 & 69.89 & 10.43 & 2472 & 2.28 & 0.224 \\
\hline \multicolumn{14}{|l|}{ Covered } \\
\hline \multicolumn{14}{|c|}{ Top watered } \\
\hline CLF & BPNC & 8.7 & 8.45 & 1.38 & 304 & 0.46 & 0.341 & 19.6 & 58.32 & 10.27 & 2539 & 1.39 & 0.129 \\
\hline CLF & HPNC & 8.0 & 6.88 & 1.15 & 260 & 0.22 & 0.167 & 16.5 & 52.26 & 7.67 & 1916 & 1.02 & 0.141 \\
\hline SLF & BPNC & 9.3 & 9.63 & 1.54 & 341 & 0.49 & 0.300 & 20.8 & 77.49 & 11.03 & 2721 & 1.41 & 0.143 \\
\hline SLF & HPNC & 7.7 & 6.14 & 0.97 & 234 & 0.29 & 0.281 & 18.2 & 59.92 & 8.55 & 2198 & 1.20 & 0.144 \\
\hline \multicolumn{14}{|c|}{ Subirrigated } \\
\hline CLF & BPNC & 8.3 & 6.58 & 1.12 & 261 & 0.29 & 0.245 & 15.8 & 39.30 & 6.10 & 1454 & 1.38 & 0.226 \\
\hline CLF & HPNC & 4.8 & 3.36 & 0.54 & 135 & 0.07 & 0.146 & 9.6 & 12.42 & 2.17 & 464 & 0.39 & 0.200 \\
\hline SLF & BPNC & 10.7 & 10.88 & 1.80 & 410 & 0.50 & 0.255 & 20.4 & 62.15 & 9.39 & 2260 & 1.92 & 0.214 \\
\hline SLF & HPNC & 6.4 & 4.23 & 0.69 & 174 & 0.08 & 0.111 & 12.8 & 19.60 & 3.16 & 768 & 0.70 & 0.227 \\
\hline \multicolumn{14}{|c|}{ Significance } \\
\hline \multicolumn{2}{|c|}{ Irrigation method (IM) } & NS & NS & NS & NS & NS & NS & $* * *$ & $* *$ & $* * *$ & $* * *$ & * & $* *$ \\
\hline \multicolumn{2}{|c|}{ Fertilization regime (FR) } & $* * *$ & $* * *$ & $* * *$ & $* * *$ & $* * *$ & NS & $* * *$ & $* * *$ & $* * * *$ & $* * *$ & $* * *$ & * \\
\hline \multicolumn{2}{|c|}{ Preplant nutr. charge (PNC) } & $* * *$ & $* * *$ & $* * *$ & $* * *$ & $* * *$ & $* *$ & $* * *$ & $* * *$ & $* * *$ & $* * *$ & $* * *$ & NS \\
\hline \multicolumn{2}{|c|}{$\mathrm{FR} \times \mathrm{PNC}$} & * & $* * *$ & $* *$ & $* *$ & NS & NS & $*$ & NS & NS & NS & NS & NS \\
\hline \multicolumn{2}{|c|}{$\mathrm{IM} \times \mathrm{FR}$} & $* *$ & $* *$ & $* *$ & $* *$ & NS & $*$ & NS & NS & NS & NS & NS & NS \\
\hline \multicolumn{2}{|c|}{$\mathrm{IM} \times \mathrm{PNC}$} & $*$ & $* *$ & $* *$ & $* *$ & $* * *$ & $* *$ & $* * *$ & $* * *$ & $* * *$ & $* * *$ & NS & NS \\
\hline \multicolumn{2}{|c|}{$\mathrm{IM} \times \mathrm{FR} \times \mathrm{PNC}$} & NS & $\mathrm{NS}$ & NS & NS & NS & NS & NS & NS & $* *$ & $* *$ & NS & NS \\
\hline \multicolumn{2}{|c|}{ Evaporation barrier (EB) } & $* * *$ & $* *$ & $*$ & $* *$ & $* * *$ & $* * *$ & $* * *$ & $* * *$ & $* * *$ & $* * *$ & $* * *$ & NS \\
\hline \multicolumn{2}{|c|}{$\mathrm{IM} \times \mathrm{EB}$} & NS & $*$ & $*$ & $*$ & NS & NS & $* * *$ & $* * *$ & $* * *$ & $* * *$ & $* * *$ & NS \\
\hline \multicolumn{2}{|c|}{$\mathrm{FR} \times \mathrm{EB}$} & NS & NS & NS & NS & NS & NS & NS & $* *$ & $* * *$ & $* * *$ & $* * *$ & NS \\
\hline \multicolumn{2}{|c|}{$\mathrm{PNC} \times \mathrm{EB}$} & $* * *$ & $* * *$ & $* * *$ & $* * *$ & $* *$ & NS & $* * *$ & $* * *$ & $* * *$ & $* * *$ & $* * * *$ & NS \\
\hline \multicolumn{2}{|c|}{$\mathrm{FR} \times \mathrm{PNC} \times \mathrm{EB}$} & NS & $*$ & $*$ & NS & NS & NS & $* *$ & $* * *$ & $* * *$ & * & NS & NS \\
\hline $\mathrm{IM} \times \mathrm{I}$ & & NS & * & NS & NS & NS & NS & $* * *$ & NS & $* *$ & $* *$ & $*$ & NS \\
\hline $\mathrm{IM} \times \mathrm{I}$ & & $* *$ & NS & NS & $* *$ & $*$ & $*$ & $* *$ & $* * *$ & $* *$ & $* *$ & $* * *$ & $*$ \\
\hline $\mathrm{IM} \times \mathrm{I}$ & $\mathrm{C} \times \mathrm{EB}$ & NS & NS & NS & NS & NS & NS & NS & NS & NS & NS & NS & NS \\
\hline
\end{tabular}


1987). Plant growth was reduced when root-zone nutrient concentrations were at optimal levels for an SME and was further reduced at nutrient concentrations above the optimal range.

The root media used in this experiment contained a PNC. Increasing the PNC did not directly affect shoot growth of plants grown in pots without an EB. In the uncovered pots, much of the PNC did not remain in the root zone and either moved to the top layer or was leached from the pot. In the covered plants, nutrient concentrations were higher, indicating a greater persistence of the preplant charge in the root zone, but the higher intensity limited the initial growth of the plants. Currently recommended preplant nutrient levels of 0.1 to $0.2 \mathrm{~kg} \cdot \mathrm{m}^{-3}$ mineral $\mathrm{N}$ are adequate for initial growth.

At day 54, irrigation method did not affect shoot growth characteristics of plants grown in the uncovered pots (Table 2). George (1989) determined that subirrigation produced plants similar in quality to those that were top watered. However, a lower fertilizer concentration was used with subirrigation in those experiments to reduce the chance of fertilizer buildup in the root media of subirrigated plants. In this experiment, the same high fertilizer concentration was used with both top watering and subirrigation without reducing the growth of the uncovered subirrigated plants.

SLF plants had greater shoot height, shoot fresh and dry weight, leaf area, and root dry weight compared to those of CLF plants with both irrigation methods, but with the $\mathrm{EB}$, the reduction in growth characteristics from the CLF treatments was greater with subirrigation than with top watering. The HPNC had no effect on

Table 3. Amount of water used and nitrogen fertilizer applied to poinsettias over the 8-week period for uncovered pots and pots covered with an evaporation barrier $(\mathrm{EB}) . \mathrm{CLF}=$ constant liquid fertilizer; $\mathrm{SLF}=$ schedule-increasing liquid fertilizer; BPNC = base preplant nutrient charge; HPNC $=$ high preplant nutrient charge. Data represent mean of six values.

\begin{tabular}{|c|c|c|c|c|c|c|}
\hline \multirow[b]{2}{*}{ Pots } & & \multicolumn{2}{|c|}{ Days 0-21 } & \multicolumn{2}{|c|}{ Days $21-54$} & \multirow{2}{*}{$\begin{array}{r}\text { Total } \\
\text { applied } \\
\text { WSF-N } \\
\text { (g/pot) }\end{array}$} \\
\hline & & $\begin{array}{l}\text { No. of } \\
\text { irrigations }\end{array}$ & $\begin{array}{c}\text { Plant } \\
\text { water use } \\
\text { (liters) }\end{array}$ & $\begin{array}{l}\text { No. of } \\
\text { irrigations }\end{array}$ & $\begin{array}{c}\text { Plant } \\
\text { water use } \\
\text { (liters) }\end{array}$ & \\
\hline \multicolumn{7}{|l|}{ Uncovered pols } \\
\hline \multicolumn{7}{|l|}{ Top watered } \\
\hline CLF & BPNC & 5 & 2.22 & 7 & 3.63 & 3.60 \\
\hline CLF & HPNC & 5 & 2.08 & 6 & 3.26 & 3.30 \\
\hline SLF & BPNC & 5 & 2.31 & 7 & 3.51 & 2.33 \\
\hline SLF & HPNC & 5 & 2.29 & 10 & 4.80 & 3.08 \\
\hline \multicolumn{7}{|l|}{ Subirrigated } \\
\hline CLF & BPNC & 5 & 1.49 & 11 & 3.62 & 2.08 \\
\hline CLF & HPNC & 5 & 1.48 & 11 & 3.59 & 2.08 \\
\hline SLF & BPNC & 6 & 1.81 & 12 & 3.70 & 1.66 \\
\hline SLF & HPNC & 5 & 1.32 & 14 & 4.52 & 1.95 \\
\hline \multicolumn{7}{|l|}{ Covered pots } \\
\hline \multicolumn{7}{|l|}{ Top watered } \\
\hline CLF & BPNC & 3 & 0.84 & 5 & 2.75 & 2.40 \\
\hline CLF & HPNC & 2 & 0.55 & 4 & 1.75 & 1.80 \\
\hline SLF & BPNC & 3 & 0.87 & 7 & 3.32 & 2.03 \\
\hline SLF & HPNC & 2 & 0.52 & 5 & 2.40 & 1.58 \\
\hline \multicolumn{7}{|l|}{ Subirrigated } \\
\hline CLF & BPNC & 3 & 0.56 & 6 & 2.20 & 1.17 \\
\hline CLF & HPNC & 2 & 0.27 & 3 & 0.85 & 0.65 \\
\hline SLF & BPNC & 4 & 0.85 & 9 & 3.03 & 1.20 \\
\hline SLF & HPNC & 2 & 0.37 & 4 & 1.10 & 0.59 \\
\hline \multicolumn{7}{|l|}{ Significance } \\
\hline Irrigation method (IM) & & & $* * *$ & & $*$ & \\
\hline Fertilization regime (FR) & & & $* * *$ & & $* * *$ & \\
\hline Preplant nutrient charge (PNC) & & & $* * *$ & & $* * *$ & \\
\hline $\mathrm{FR} \times \mathrm{PNC}$ & & & $* * *$ & & $* * *$ & \\
\hline $\mathrm{IM} \times \mathrm{FR}$ & & & NS & & NS & \\
\hline $\mathrm{IM} \times \mathrm{PNC}$ & & & $* *$ & & $* * *$ & \\
\hline $\mathrm{IM} \times \mathrm{FR} \times \mathrm{PNC}$ & & & $* * *$ & & $* * *$ & \\
\hline EB & & & $* * *$ & & $* * *$ & \\
\hline $\mathrm{IM} \times \mathrm{EB}$ & & & $* * *$ & & $* * *$ & \\
\hline $\mathrm{FR} \times \mathrm{EB}$ & & & NS & & NS & \\
\hline $\mathrm{PNC} \times \mathrm{EB}$ & & & $* * *$ & & $* * *$ & \\
\hline $\mathrm{FR} \times \mathrm{PNC} \times \mathrm{EB}$ & & & NS & & $* * *$ & \\
\hline $\mathrm{IM} \times \mathrm{FR} \times \mathrm{EB}$ & & & $* * *$ & & NS & \\
\hline $\mathrm{IM} \times \mathrm{PNC} \times \mathrm{EB}$ & & & NS & & $* * *$ & \\
\hline $\mathrm{IM} \times \mathrm{FR} \times \mathrm{PNC} \times \mathrm{EB}$ & & & $* *$ & & NS & \\
\hline
\end{tabular}

NS,*,**,*** Nonsignificant or significant at $P=0.05,0.01$, or 0.001 , respectively. 
the growth of either top-watered or subirrigated uncovered treatments. However, with the EB, the five characteristics of plants grown in media containing the BPNC were greater than those of plants grown in media containing the HPNC. but the difference between BPNC and HPNC treatments was greater with subirrigation than with top watering.

Plant water use. Without the barrier. $46 \%$ more water was used by top-watered plants between planting and the first harvest than by subirrigated plants (2.2 vs. 1.5 liters) (Table 3$)$. Water use was similar for top-watered and subirrigated plants between days 21 and 54. With the barrier. the average amount of water used decreased by $68 \%$ from planting until the first harvest and $43 \%$ between the first and second harvest compared to that of the uncovered pots. Over the 8 weeks of the experiment, average water use decreased by $51 \%$.

Plants with similar leaf area can be directly compared to determine the amount of water lost from evaporation compared to transpiration. Top-watered plants with and without the EB were similar in leaf area when averaged over all treatments (Table 2). Water lost to evaporation from the root-medium surface accounted for $\approx 60 \%$ of the total amount of water used by the plant during the first 3 weeks after planting (Table 3 ). For the remaining 5 weeks of the experiment, water loss of top-watered plants to evaporation from the surface of the root medium accounted for $33 \%$ of the total water used. In comparison. Furuta et al. (1977) measured a $26 \%$ reduction in water use of mature Monterary pines with the rootmedium surface covered. Subirrigated plants were not similar in leaf area at either harvest (Table 2). so a direct comparison could not be made.

Applied WSF. In the uncovered pots, subirrigated plants received an average of $58 \%$ less WSF $\mathrm{N}$ than did top-watered treatments ( $1.9 \mathrm{~g}$ vs. $3.1 \mathrm{~g} \mathrm{~N}$ ) (Table 3). although similar root-zone nutrient levels were measured with both irrigation methods at week 8 (Table 1). The difference in the amount of applied fertilizer between subirrigated and top-watered plants reflects the amount of fertilizer wasted because of $\mathrm{N}$ leaching out of the pot.

Forty-three percent less $\mathrm{N}$ fertilizer was applied to plants with the EB than the uncovered plants averaged over all treatments (Table 3). With top watering. plants of similar size and root-zone nutrient concentrations were obtained with $37 \%$ less applied $\mathrm{N}$ fertilizer (Tables 1-3). With subirrigation, 53\% less fertilizer was applied to the plants grown in pots covered with the EB, but the difference is partially due to differences in plant growth between the subirrigated uncovered and covered plants.

\section{Conclusions}

Top watering with leaching and subirrigation produced plants of similar size at both sampling dates using the same fertilizer concentration when surface evaporation was not limited. The accumulation of the fertilizer salts in the top layer of the pot with subirrigation, caused by evaporation from the root-medium surface, reduced root-zone nutrient concentrations similar to the removal of fertilizer salts by leaching surface-applied water from the bottom of the container. With subirrigation, high concentrations of applied fertilizer were not detrimental to plant growth because much of the applied fertilizer moved through the root zone into the top layer of the pot.

Top watering with leaching produced larger plants than subirrigation when surface evaporation was reduced with the EB. When high concentrations of fertilizer were applied early after planting to subirrigated plants. much of the fertilizer salts remained in the root zone, limiting plant growth compared to the uncovered subirrigated treatments. With top watering. fertilizer salts were still removed from the root zone with leaching. resulting in similar plant growth in the uncovered and covered treatments. The outcome of any fertilizer experiment using subirrigation may depend, to some extent. on the amount of evaporation-induced salt stratification within the pot. Further study is needed to determine factors that influence evaporation from the root-medium surface.

Recommendations for the initial application of fertilizer to poinsettias do not consider the presence or absence of a PNC (Berghage et al., 1987: Sheldrake, 1987). If the PNC is present. the application of high concentrations of WSF $\left(28 \mathrm{~mol} \mathrm{~N} / \mathrm{m}^{3}\right)$ early is not necessary. However, in situations in which no preplant fertilizer is incorporated or the preplant fertilizer was leached during mist propagation, the application of high concentrations of WSF may be necessary. For example, 0.5 liters of the $28 \mathrm{~mol} \mathrm{~N} / \mathrm{m}^{3}$ solution applied to a $15-\mathrm{cm}$ (1.7-liter) pot would add the equivalent of $0.09 \mathrm{~kg} \mathrm{~N} / \mathrm{m}^{3}$ of media. or roughly $36 \%$ to $45 \%$ of the maximum amount recommended by Bunt (1988).

Recommendations for the continued fertilization of poinsettias are based solely on the concentration of the applied WSF (Berghage et al., 1987; Sheldrake, 1987) and were probably based on the assumption that the plants were irrigated with Icaching. $\mathrm{Ku}$ and Hershey (1991) and Yelanich and Biernbaum (1993) demonstrated that several root-medium nutrient concentrations could be obtained with a single WSF concentration by changing the leaching fraction. In this experiment, surface evaporation also affected rootzone nutrient concentrations. Thus, fertilization recommendations based on WSF concentrations alone arc of limited value even when leaching is prevented.

The amount of water lost from the root medium due to surface evaporation affected irrigation frequency and the amount of $\mathrm{N}$ fertilizer applied to the pot. Reducing the amount of WSF applied with the use of an EB affected root-zone nutrient concentrations, but they were similar or higher in the covered than the uncovered medium. Thus. fertilization frequency is not necessarily a good indicator of root-zone nutrient concentrations. as Argo and Biernbaum (1994) concluded using subirrigated Easter Lilies. Emphasis should be placed on maintaining desired root-zone nutrient concentrations rather than only managing the applied WSF concentration.

When sampling container root media. it is sometimes recommended to avoid the top layer because of the presence of high levels of fertilizer salts (Nelson, 1991). However. other authors recommend taking root-medium samples from a complete profile of the pot (Bethke, 1985). Yelanich and Biernbaum (1993) removed the top layer in subirrigated plants but used a combination of the whole profile for soil tests in top watered plants. High concentrations of fertilizer salts contained in the top layer could alter the concentration of any nutrient tested if the top layer were included in the sample. For example, commercial greenhouse operators switching from sampling the entire profile to sampling only the bottom layer noted a reduction in root-media nutrient concentrations (1992 Kalamazoo Valley Coop. grower meeting, personal communication).

Recommended optimal EC levels in the root medium arc bctween 2.0 and $3.5 \mathrm{dS} \cdot \mathrm{m}^{-1}$ for established plants using an SME (Warncke and Krauskopf. 1983). but it is unclear whether these recommended levels are based on samples including the top layer. Therefore. an emphasis should be placed on the consistency of the sampling method and refining of recommended nutrient levels based on a specific sampling method. In our opinion. sampling the root zone probably provides a more accurate measure of nutrient availability to the plant. 


\section{Literature Cited}

Argo, W.A. and J.A. Biernbaum. 1994. Irrigation requirements, rootmedium $\mathrm{pH}$ and nutrient concentrations of Easter lilies grown in five peat-based media with and without an evaporation barrier. J. Amer. Soc. Hort. Sci. 119:1151-1156.

Beardsell, D.V., D.G. Nichols. and D.L. Jones. 1979. Water relations of nursery potting-media. Scientia Hort. 11:9-17.

Berghage, R.D., R.D. Heins, W.H. Carlson, and J.A. Biernbaum. 1987. Poinsettia production. Mich. State Univ. Ext. Bul. E-1382.

Bethke, C.L. 1985. Balancing soil nutrients. Greenhouse Manager 6(8):57-67.

Bunt, A.C. 1988. Media and mixes for container-grown plants. 2nd ed. Unwin Hyman, London. Furuta, T., T. Mock, and R. Coleman. 1977. Estimating the water needed for container-grown nursery stock. Amer. Nurseryman 145(8):68-73.

George, R.K. 1989. Flood subirrigation systems for greenhouse production and the potential for disease spread. MS thesis. Michigan State Univ., East Lansing.

Guttormsen, G. 1969. Accumulation of salts in the sub-irrigation of pot plants. Plant soil 21(3):425-438.

Havis, J.H. 1982. Applying slow-release fertilizer in container nurseries with capillary watering. Amer. Nurseryman 156(4):24-28,32.

$\mathrm{Ku}$, C.S.M. and D.R. Hershey. 1991. Leachate electrical conductivity and growth of potted poinsettia with leaching fractions of 0 to 0.4. J. Amer. Soc. Hort. Sci. 116:802-806.

Laurie, A. and V.H. Ries. 1950. Floriculture: fundamentals and practices. 2nd ed. McGraw-Hill, New York.

Molitor, H.D. 1990. The European perspective with emphasis on subirrigation and recirculation of water and nutrients. Acta Hort. 272: 165 173.

Nelson, P.V. 1991. Greenhouse operation and management. 4th ed. Reston Publishing Co. Reston, Va.

SAS Institute. 1982. SAS user's guide and SAS statistical procedures. SAS Inst., Cary, NC.

Sheldrake, R. 1987. Grower guidelines: Growing poinsettias my way. Benchmarks 4(2):1-3.

Warncke, D.D. and D.M. Krauskopf. 1983. Greenhouse growth media: Testing and nutrition guidelines. Michigan State Univ. Ext. Bul. D1736.

Warncke, D.D. 1986. Analyzing greenhouse growth media by the saturation extraction method. HortScience 21:223-225.

Yelanich, M.V. and J.A. Biernbaum. 1993. Root-medium nutrient concentration and growth of poinsettia at three fertilizer concentrations and four leaching fractions. J. Amer. Soc. Hort. Sci. 118:771-776.

Yelanich, M.V. 1991. Methods to improve fertilization to minimize nitrogen runoff. MS thesis. Michigan State Univ., East Lansing. 